\title{
Some Serum Oxidative Parameters in Normoglycemic Rats: Vascular Endothelial Growth Factor (VEGF) Application
}

\author{
Kaan Kaltalioglu' ${ }^{\text {(D) }}$ Sule Coskun Cevher ${ }^{2}$ (iD \\ ${ }^{1}$ Giresun University, Espiye Vocational School, Giresun, Turkey \\ ${ }^{2}$ Gazi University, Department of Biology, Ankara, Turkey
}

\section{A BSTRACT}

V EGF has the positive effect on wound healing. In this study, the effect of VEGF application on some serum parameters during wound healing process were investigated. 36 female normoglycemic Wistar rats were used (200-250 g). Dorsolateral incisional wounds (length: $4 \mathrm{~cm}$ ) were made on the two sides of the medulla spinalis in rats. They were divided into 3 groups: untreated group $(n=12)$, chitosan group $(n=12)$ and chitosan+VEGF group $(n=12)$. The rats were sacrificed on the 3 rd and 7 th days of post wounding. NOx, TBARs and RSH levels were determined spectrophotometrically in serum. Results were compared by one-way ANOVA $(\mathrm{p}<0.05)$. Serum TBARs levels both the chitosan treated group and the VEGF application group was found decreased when compared with untreated groups (3rd and 7th days) ( $\mathrm{p}<0.05$ ). Chitosan and VEGF application were effective increasing antioxidant capacity of serum on the 7 th day. Serum NOx levels decreased in the VEGF treated groups on $3 \mathrm{rd}$ and on 7 th days $(\mathrm{p}<0.05)$. It can be considered that VEGF administration has a more positive systemic effect to eliminate increased oxidative damage in the serum of normoglycemic rats.

Keywords:

VEGF application; Chitosan; Wound healing; Oxidative stress; Antioxidant.

\author{
Article History: \\ Received: 2019/11/17 \\ Accepted: 2020/02/13 \\ Online: 2020/03/26
}

Correspondence to: Sule Coskun Cevher, Gazi University, Science Faculty, Biology Department, 06500, Ankara, Turkey

E-Mail:sule@gazi.edu.tr

Phone: +903122021196

Fax: +903122021171

\section{INTRODUCTION}

W ound healing is essentially a science in which physiological and biochemical events occur at the highest level. The phases of normal wound healing are inflammation, proliferation and remodeling which cannot be completely separated from each other [1-5].

VEGF have different biological properties and bioavailability which consists of 6 isoforms in humans [6-8]. VEGF shows its effects via binding to tyrosine kinase receptors, VEGF receptor 1 and VEGF receptor 2 . It has been known that hypoxia and also numerous cytokines and growth factors such as interleukin-6 (IL-6), IL-1 $\beta$, epidermal growth factor (EGF) and transforming growth factor- $\beta$ (TGF- $\beta$ ) increase VEGF expression [9].

VEGF, which contains cysteine-cysteine bonds, and chitosan, which contains active $-\mathrm{OH} /-\mathrm{NH}_{2}$ groups $[9,10]$, may influence the redox balance besides their contributions to wound healing process.

VEGF is produced by various cell types such as thrombocytes, fibroblasts, macrophages, smooth musc- le cells and neutrophils during wound healing process and it has receptors on endothelial cells and monocytes [9]. VEGF is a powerful mitogen factor for the endothelial cells of the lymph, arteries and veins, but lacks any mitogenic activity on other cells [9]. It has been known that VEGF synthesized in the wound bed peaked at 3-7 days and then gradually decreased at 7-14 days [9].

At very low concentrations $(\mu \mathrm{M}), \mathrm{H}_{2} \mathrm{O}_{2}$ induces VEGF-A expression. It has also been proven that oxidants such as $\mathrm{H}_{2} \mathrm{O}_{2}$ and $\mathrm{NO}$ promote VEGF synthesis, and N-Acetyl-L-cysteine, a GSH precursor, also inhibits angiogenesis by suppressing VEGF gene expression [11, $12]$.

It has been reported that the disruption of synthesis of VEGF and its mediator (NO) due to excessive oxidative stress in diabetes leads to the deterioration of wound healing phases [1-4, 13,14].

Chitosan is a polysaccharide consists of $\beta-(1-4)$ linked D-glucosamine and $\mathrm{N}$-acetyl-D-glucosamine units. It is obtained commercially from chitin by dea- 
cetylation, which is in the cell walls of some bacteria and fungi. It has been shown that chitosan attracts inflammatory cells and growth factors released from them into the wound site in the early period of wound healing process [15]. Moreover, it has been reported that it has antioxidant effect thanks to its hydroxyl and amino groups [10].

On this basis, in our study, VEGF in chitosan gel were topically administered to the wound in normoglycemic rats. It was investigated how they affect the values of serum oxidative parameters such as TBARs and NOx levels, and RSH levels.

\section{MATERIAL AND METHODS}

Ethical approval for this study was obtained from Gazi University Local Ethics Committee for Animal Experiments (G.ET-10.117). Chitosan (C3646) and VEGF (Sigma V3638) were obtained from Sigma-Aldrich. 1\% Lactic acid was added to $50 \mathrm{~mL}$ deionized water. $3 \mathrm{~g}$ chitosan was added to solution and stirred. After, $50 \mathrm{~mL}$ deionized water was added and mixed. Obtained gel was kept at room temperature overnight before the application. Finally, 417 ng VEGF was added to obtained chitosan gel (last concentration $7 \mathrm{ng} / \mathrm{mL}$ )

\section{Animals}

All of the rats were kept on standard rodent cages with appropriate amounts of rat food and water. Rats were kept with normal light-dark cycle $(12: 12 \mathrm{~h})$ at room temperature $\left(25 \pm 2{ }^{\circ} \mathrm{C}\right)$.

\section{Wound Model}

The animals were anaesthetized with a combination of xylazine and ketamine intramuscularly. The dorsal section of rats was shaved an electric razor, and cleaned with $1 \%$ iodine tincture. $4 \mathrm{~cm}$ lengthy - incisional wound models were made on the two sides of medulla spinalis on the rats. 36 healthy normoglycemic rats were divided into 3 groups. There were 6 rats in each group: untreated group $(n=12)$, chitosan treated group $(n=12)$ and chitosan + VEGF group ( $\mathrm{n}=12)(7 \mathrm{ng} / \mathrm{ml}$ VEGF). Each group was divided into two in itself to be sacrificed on the 3rd and the 7 th days.

\section{Biochemical Analyses}

\section{Determination of TBARs levels}

The TBARs levels of serum samples were analyzed according to Kurtel et al. [16]. The absorbance was read at $532 \mathrm{~nm}$.

\section{Determination of RSH levels}

Plasma RSH was determined by spectrophotometric method [17]. The absorbance was read at $412 \mathrm{~nm}$. RSH amount was determined assuming a molar absorption coefficient of 13.000 at $412 \mathrm{~nm}$ for 5-thio-2-nitrobenzoic acid (TNB).

\section{Determination of $\mathrm{NOx}$ levels}

The plasma NOx levels were measured using Griess reaction. Sodium nitrite and sodium nitrate solutions were used as standards [18].

\section{Statistical Analysis}

The data were given as the mean \pm standard deviation (SD). Mean values were compared by one-way ANOVA. The level of statistically significance was set at $\mathrm{P}<0.05$.

\section{RESULTS}

The obtained results are shown in Table 1.

\section{Serum TBARs Level}

Serum TBARs levels both the chitosan treated group and the VEGF application group was found decreased when compared with untreated groups (day 3 and day 7) (p $<0.05$ ). The most significant reduction occurred in the chitosan group. It can be said that use of chitosan decreased lipid peroxidation in the rat serum. There weren't any significant alterations between the chitosan and VEGF treated group when compared with each other both 3 and 7 days $(\mathrm{p}>0.05)$ (Fig 1$)$.

\section{Serum RSH Level}

When the chitosan group were compared with the untreated group on the 7th day, the serum RSH levels of the chitosan group showed a statistically significant increase. In addition, when the VEGF treated group were compared with the untreated group, the serum RSH level

\section{TBARs levels}

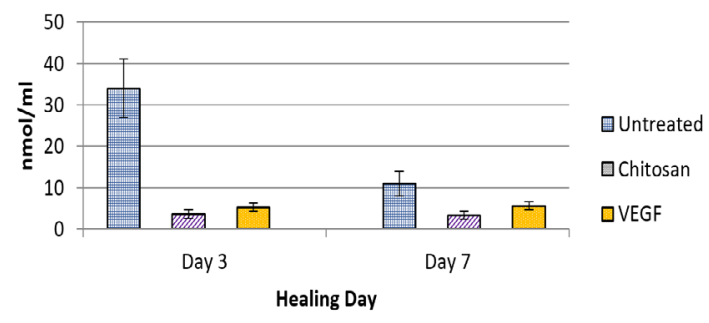

Figure 1. Serum TBARs levels. 
Table 1 Serum TBARS, RSH and NOx levels in rats

\begin{tabular}{llll}
\hline & TBARS level $(\mathrm{nmol} / \mathrm{ml})$ & RSH level $(\mathrm{nmol} / \mathrm{ml})$ & NOx level $(\mu \mathrm{mol} / \mathrm{l})$ \\
\hline Untreated groups & & & \\
\hline Day 3 & $33.99 \pm 7.73 \mathrm{c}, \mathrm{e}$ & $234.32 \pm 2.54 \mathrm{~g}$ & $9.51 \pm 1.94$ \\
Day 7 & $10.98 \pm 3.03 \mathrm{~d}, \mathrm{f}, \mathrm{g}$ & $51.47 \pm 4.80$ & $10.50 \pm 2.28 \mathrm{f}$ \\
\hline Chitosan treated groups & & & $8.28 \pm 2.78$ \\
\hline Day 3 & $3.57 \pm 1.14 \mathrm{a}$ & $223.15 \pm 2.78 \mathrm{~g}$ & $10.62 \pm 2.67 \mathrm{f}$ \\
Day 7 & $3.32 \pm 0.84 \mathrm{~b}$ & $393.55 \pm 9.20 \mathrm{~b}$ & \\
\hline Chitosan + VEGF groups & & & $4.22 \pm 0.74 \mathrm{a}, \mathrm{c}$ \\
\hline Day 3 & $5.23 \pm 1.85 \mathrm{a}, \mathrm{c}$ & $146.18 \pm 3.12 \mathrm{a}, \mathrm{c}, \mathrm{g}$ & $1.45 \pm 0.37 \mathrm{~b}, \mathrm{~d}, \mathrm{~g}$ \\
\hline Day 7 & $5.60 \pm 1.13 \mathrm{~b}, \mathrm{~d}$ & $248.78 \pm 5.40 \mathrm{~d}, \mathrm{~b}$ & \\
\hline
\end{tabular}

${ }^{a} p<0.05$ when compared to untreated group (day 3 ), b $p<0.05$ when compared to untreated group (day 7 ), ${ }^{c} p<0.05$ when compared to chitosan treated group (day 3 ), ${ }^{d} p<0.05$ when compared to chitosan treated group (day 7 ),

${ }^{e} p<0.05$ when compared to VEGF treated group (day 3 ),

${ }^{f} p<0.05$ when compared to VEGF treated group (day 7 ),

${ }^{g} p<0.05$ when compared to 3 and 7 day in the same group

of VEGF treated group showed a statistically significant increase on the 7th day. The serum RSH levels increased both chitosan treated group and VEGF group on the 7th day. Chitosan and VEGF application were effective increasing antioxidant capacity of serum on the 7th day (Fig 2).

\section{Serum NOx Level}

When VEGF treated groups were compared both the untreated groups and chitosan groups, $\mathrm{NOx}$ levels decreased in the VEGF treated groups on 3rd and on 7th days ( $p$ $<0.05$ ). According to these results, it is seen that chitosan application did not change NOx levels when compared to untreated group. VEGF application decreased statistically significant in point of serum NOx levels $(\mathrm{p}<0.05)$. VEGF administration decreased serum NO levels on both 3rd and 7th days of wound healing independent of chitosan. These results suggested that VEGF administration may have been effective by suppressing NOS enzyme levels in healthy rats (Fig 3).

\section{DISCUSSION}

There is information about that high levels of ROS are harmful by suppressing the synthesis of VEGF and its

\section{RSH levels}

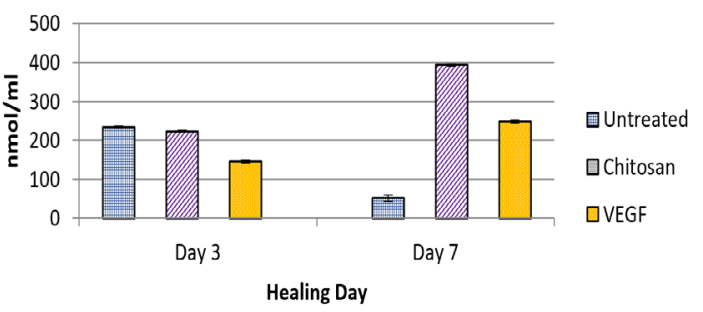

Figure 2. Serum RSH levels. mediator (NO) in the newly developed wound tissue and that micro-levels of ROS (H2O2 and NO) are beneficial by stimulating VEGF synthesis and signaling [19-21]. Although there is no infection in the wound, it has been understood that micro-levels of oxidants formed by respiratory burst are necessary to initiate various signal processes.

Jones et al. [22] reported that cysteine-cysteine bonds present in proteins received oxidative signals from the surrounding area by the conversion of thiols to disulfides. It has been indicated that the conversion of thiols to disulfides stimulates various molecular pathways in both mitochondria and cell nuclei by leading a change in protein-DNA and protein-protein interactions [23,24]. VEGF is also a growth factor that carries cysteine-cysteine bonds in its structure. Its synthesis and signaling are stimulated by oxidants such as $\mathrm{H} 2 \mathrm{O} 2$ and $\mathrm{NO}$ and are inhibited by antioxidants such as GSH and N-acetyl cysteine (NAC) [21]. It has also been reported that inadequate VEGF synthesis is effective in disrupting the redox balance of the cell. Because it has been suggested that when VEGF is released, it initiates contradictory processes that show an antioxidant effect with mitochondrial Mn-SOD and an oxidant effect with NADPH oxidase [21]. VEGF may provide a balance between oxidant

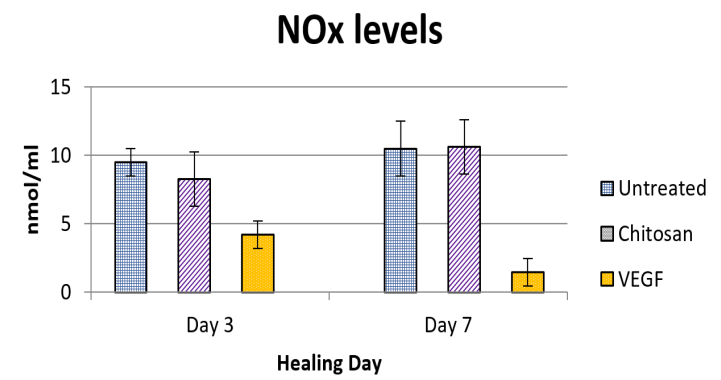

Figure 3. Serum NOx levels. 
and antioxidants.

In the current study, firstly, when the chitosan and VEGF+chitosan groups were compared with the untreated group TBARs levels of the chitosan and VEGF+chitosan groups showed a decrease from the 3rd day to the 7th day. The most significant reduction occurred in the chitosan group. Both chitosan and VEGF are agents that affect the oxidation process in the media. It can be said that chitosan and VEGF showed an antioxidant effect in wound serum of healthy rats by reducing the lipid oxidation. Sönmez Çoban and Coşkun-Cevher [25] suggested that VEGF administration decreased serum TBARS levels compared to both diabetic control groups and chitosan treated diabetic groups. These results indicate that both chitosan and VEGF administration reduced lipid peroxidation in both normoglycemic and hyperglycemic rats.

When the chitosan group were compared with the untreated group on the 7th day, the serum RSH levels of the chitosan group showed a dramatically significant increase. In addition, when the VEGF treated group were compared with the untreated group, the serum RSH level of VEGF treated group showed a statistically significant increase on the 7th day. The serum RSH levels increased both chitosan treated group and VEGF group on the 7th day. Chitosan and VEGF application were effective increasing antioxidant capacity of serum on the 7th day (Table 1). On the 7th day corresponding to the proliferation phase of wound healing serum RSH levels were increased. Both chitosan and VEGF administration increased serum antioxidant capacity. This increase was most prominent on day 7. Similarly, in the study performed by Sönmez Çoban and Coşkun-Cevher [25] in diabetic rats, increased serum RSH levels were detected on the 7th day of wound healing compared to diabetic control by VEGF application. In our study, it is thought that this effect may be due to the molecular structure of VEGF itself as an antioxidant.

According to our results, chitosan application did not change NOx levels when compared to untreated group. VEGF administration decreased serum NO levels on both 3rd and 7th days of wound healing independent of chitosan. These results suggested that VEGF administration may have been effective by suppressing NOS enzyme levels in healthy rats. Sönmez Çoban and Coşkun-Cevher [25] in their study, showed that both chitosan administration and exogenous VEGF administration increased serum $\mathrm{NO}$ levels in hyperglycemic rats. In contrast, we found that topical administration of VEGF reduced serum NO levels in normoglycemic rats. There is a relation between $\mathrm{NO}$ and VEGF in wound healing process; namely $\mathrm{NO}$ is one of the mediators of VEGF activity in terms of collagen deposition, nerve conduction, tissue oxygenation and restoration of en- dothelial function [20,26].

\section{CONCLUSION}

It may be thought that the application may have an effect on reducing oxidative stress. Further studies are needed to determine the under various conditions in relation to VEGF applications, which have an important role in wound healing.

\section{ACKNOWLEDGEMENT}

The authors would like to thanks Gazi University Research fund (Project number: G.Ü. BAP 05/2011-01) for their financial supports.

\section{References}

1. Harding KG, Morris HL, Patel GK. Science, medicine and the future: Healing chronic wounds. BMJ 324 (2002) 160-163.

2. Fahey TJ, Sadaty A, Jones WG, Barbe A, Smoller B, Shires GT. Diabetes impairs the late inflammatory response to wound healing. J Surg Res 50 (1991) 308-313.

3. Lerman OZ, Galiano RD, Armour M, Levine JD, Gurtner, GC. Cellular dysfunction in the diabetic fibroblast. Am J Pathol 162 (2003) 303-312.

4. Komesu MC, Tanga MB, Buttros KR, Nakao C. Effects of acute diabetes on rat cutaneous wound healing. Pathophysiology 11 (2004) 63-67.

5. Lobmann R, Ambrosch A, Schultz G, Waldmann K, Schiweck S, Lehnert H. Expression of matrix-metalloproteinases and their inhibitors in the wound of diabetic and non-diabetic patients. Diabetologia 45 (2002) 1011-1016.

6. Ferrara N, Gerber HP, LeCouter J. The biology of VEGF and its receptors. Nat Med 9 (2003) 669-676.

7. Poltorak Z, Cohen T, Neufeld G. The VEGF splice variants: properties, receptors, and usage for the treatment of ischemic diseases. Herz 25 (2000) 126-129.

8. Tammela T, Enholm B, Alitalo K, Paavonen K. The biology of vascular endothelial growth factors. Cardiovasc Res 65 (2005) 550-563.

9. Ferrara N, Davis-Smith T. The biology of vascular endothelial growth factor. Endocr Rev 18 (1997) 4-25.

10. Sun T, Yao Q, Zhou D, Mao F. Antioxidant activity of N-carboxymethyl chitosan oligosaccharides. Bioorg Med Chem Lett 18 (2008) 5774-5776.

11. Sen CK, Khanna S, Babior BM, Hunt TK, Ellison EC, Roy S. Oxidant-induced vascular endothelial growth factor expression in human keratinocytes and cutaneous wound healing. J Biol Chem 277 (2002) 33284-33290.

12. Aktunc E, Ozacmak VH, Ozacmak HS, Barut F, Buyukates $\mathrm{M}$, Kandemir O, Demircan N. N-acetyl cysteine promotes angiogenesis and clearance of free oxygen radicals, thus improving wound healing in an alloxan-induced diabetic mouse model of incisional wound. Clin Exp Dermatol 35(2010) 902-909.

13. Roy S, Khanna S, Sen CK. Redox regulation of the VEGF signaling path and tissue vascularization: Hydrogen peroxide the common link between physical exercise and cutaneous wound healing. Free Radic Biol Med 44 (2008) 180-192. 
14. Fraisl P. Crosstalk between oxygen- and nitric oxide-dependent signaling pathways in angiogenesis. Experimental Cell Research 319 (2013) 1331-1339.

15. İnan ZDŞ. Deneysel Diyabetli Sıçanlarda Kitozanın Yara İyileşmesine Etkisinin İncelenmesi. Yüksek Lisans Tezi. HistolojiEmbriyoloji AbD. Sivas Cumhuriyet Üniversitesi Fen/Sağlık Bilimleri Enstitüsü (2009)

16. Kurtel H, Granger DN, Tso P, Grisham MB. Vulnerability of intestinal interstitial fluid to oxidant stress. Am J Physiol 262 (1992) G573-578.

17. Elmann GL. Tissue sulyphydryl groups. Arch Biochem Biophys 82 (1959) 70-77.

18. Miranda KM, Espey MG, Wink DA. A rapid, simple spectrophotometric method for simultaneous detection of nitrate and nitrite. Nitric Oxide 5 (2001) 62-71.

19. Osman AE. Vasküler Endotelial Büyüme Faktörünün Diyabetik Yara İyileşmesi Üzerine Etkileri: Farelerde Deneysel Çalışmalar. Uzmanlık Tezi. Plastik Rekonstrüktif ve Estetik Cerrahi AbD. Dokuz Eylül Üniversitesi Tıp Fakültesi (2006)

20. Bao P, Kodra A, Tomic-Canic M, Golinko MS, Ehrlich HP, Brem H. The Role of Vascular Endothelial Growth Factor in Wound
Healing. Journal of Surgical Research 153 (2008) 347-358.

21. Roy S, Khanna S, Nallu K, Hunt TK, Sen CK. Dermal wound healing is subject to redox control. Mol Ther 13 (2006) 211-220.

22. Jones DP, Go YM, Anderson CL, Ziegler TR, Kinkade JM, Kirlin WG. Cysteine/cystine couple is a newly recognized node in the circuitry for biologic redox signaling and control. FASEB J 18 (2004) 1246-1248.

23. Nathan C, Cunningham BA. Beyond oxidative stress: an immunologist's guide to reactive oxygen species. Nature Reviews Immunology 13 (2013) 349-361.

24. Reuter S, Gupta SC, Chaturvedi MM, Aggarwal BB. Oxidative stress, inflammation, and cancer: how are they linked?. Free Radic Biol Med 49 (2010) 1603-1616.

25. Sönmez Çoban V, Coşkun Cevher Ş. The Investigation of the Effect of Topical Vascular Endothelial Growth Factor (VEGF) Administration on Serum Oxidative Parameters in Diabetic Rats. Gazi University Journal of Science 29 (2016) 543-547.

26. Stojadinovic O, Kodra A, Golinko MS, Tomic-Canic M, Brem H. A novel, non-angiogenic mechanism of VEGF: Stimulation of keratinocyte and fibroblast migration. Wound Repair Regen 15 (2007) 30 . 